\title{
DAILY PHYSICAL ACTIVITY AND SEDENTARY (INACTIVE) BEHAVIOUR OF ADULTS FROM SURGUT
}

\author{
S.I. Loginov, logsi@list.ru, ORCID: 0000-0002-6640-3385 \\ Surgut State University, Surgut, Russian Federation
}

\begin{abstract}
International Physical Activity Questionnaire is commonly applied today to obtain internationally comparable data on health-related physical activity (PA). Aim. The purpose of the article is to determine the level and structure of daily physical activity in a sample of permanent residents of Surgut using the international IPAQ questionnaire. Methods. In this study, the author have made the first attempt for the last 20 years to apply a Russian version of the IPAQ to obtain data on the habitual physical activity and sedentary behavior of the Surgut city population on a sample of 1552 people ( 717 men and 835 women aged $34.4 \pm 12.6$ years) dominated by intellectual workers. Results. On the whole, the PA reported by the subjects was classified as of low $(40.7 \%)$, moderate $(36.3 \%)$ and vigorous $(23.0 \%)$ intensity. Physical activity was reported to average $25 \mathrm{~min} /$ day at work $(23 ; 26$ Confidence Interval [CI]); $17 \mathrm{~min} /$ day for transport (16; $19 \mathrm{CI})$; $18 \mathrm{~min} /$ day at home $(17,19 \mathrm{CI})$; and $12 \mathrm{~min} /$ day at discretional (leisure) time $(11,13 \mathrm{CI})$. Dispersion analysis showed the work time PA reported notably higher for men $(\mathrm{F}(1,1550)=$ $=26.676, \mathrm{p}=0.0000)$ and the transport time PA higher for women $(\mathrm{F}(1,1550)=21.801$, $\mathrm{p}=0.0000)$. The leisure-time PA was found gender-unspecific: $\mathrm{F}(1,1550)=0.00191$, $\mathrm{p}=0.9652)$. The sampled women reported more time spent for the housework: $\mathrm{F}(1,1550)=$ $=39.338, \mathrm{p}=0.0000$. The sedentary behavior was found to average $405 \pm 125 \mathrm{~min} /$ day (6.75 hours per day that is the lower limit of the health risk zone) irrespective of the gender: $\mathrm{F}(1,1550)=1.3332, \mathrm{p}=0.2484$. The study identified a few groups of people reporting variable combinations of sedentary behavior with moderate to vigorous physical activity per week. Conclusion. The study found that special PA optimization programs are critically needed to effectively scale down the share of inactive and increase the share of reasonably active population, advance the leisure-time PA and minimize the sedentary habits.
\end{abstract}

Keywords: daily physical activity, physical activity level and structure, urbanized Northern Siberia, sedentary behavior, IPAQ.

\section{Introduction}

Physical activity (PA) levels and structure are presently considered the important measures of biosocial human behavior $[2,15]$, that provide the primary means for solving the psychological and educational issue on how to lure more and more people into regular physical practices [16]. For practical purposes, the PA is now commonly classified into three levels as low $(<3 \mathrm{MET})$, moderate (3-6 MET) and vigorous ( $>6 \mathrm{MET})$ PA, with MET meaning the metabolic equivalent of $1.0 \mathrm{kcal} / \mathrm{kg} /$ hour or $3.5 \mathrm{ml} \mathrm{O}_{2} / \mathrm{kg} / \mathrm{min}$. The PA structure is classified into the following domains: work-time, housework, transport (travel-time) and discretional- (leisure-) time PA [14].

Modern researchers tend to increasingly apply such category as the so-called sedentary behavior (SB) considered rather as an independent form of socially motivated lifestyle than a physical activity domain $[4,18,24]$. The SB refers to the rapidly growing time spent sitting with very limited if any movement when watching TV, working on or playing computer, listening to or playing music, being busy with some creative work etc., with the energy expenditure (EE) varying under 1.5 MET [22]. It should be noted that many recent studies report the SB being associated with the increased risks of metabolic syndrome [21], type 2 diabetes [19], and other diseases that may be triggered by polar stress syndrome common at high latitudes [12] on the whole and in Siberia in particular [23]. To prevent health disorders, the everyday physical activity needs to be optimally designed and managed using the relevant psychological and educational process management technologies. However, the studies to consider such health management technologies are still in short supply in Russia, and this was the reason for us to make an attempt, within the frame of the Yugra Golden Age Project (YuGAP), to obtain primary data on the present levels and structure of the daily physical activity and sedentary behavior of the Surgut city population using the Russian version of the IPAQ to lay 
a basis for the psychological and educational process management technologies being applied to optimize the everyday physical activity.

\section{Materials and methods}

A random sample of 1152 residents of Surgut city including 717 men aged $32.8 \pm 12.7$ years $(36.0 \%)$ and 835 women aged $35.9 \pm 12.4$ years $(64.0 \%)$ was studied. Every subject was requested to self-report his/her PA using the long form (LF) of the IPAQ [17]. The IPAQ form is designed to obtain data on the time and energy costs of the PA leveled by low, moderate and vigorous PA additionally classified into four domains: work-time, transportation-time, housework and leisure-time PA. Every respondent was requested to recall and report the individual PA for the last 7 days in days, hours and minutes. The primary data obtained were processed as required by the standard format of the base English version of the IPAQ [3]. For the purposes of further analyses, the following intensity levels were applied: (1) low-intensity PA (LIPA < 1.52 MET), (2) moderate-intensity PA (MIPA 3-6 MET); and vigorous-intensity PA (VIPA $>7$ MET). The inactive people of predominantly sedentary behavior reporting PA under $10 \mathrm{~min} /$ day $(<60 \mathrm{MET}$ $\mathrm{min} /$ week) were classified under a separate category. Then the specific energy expenditure (EE) was calculated for every PA category as provided by the PA Compendium [1]. The specific energy expenditure (EE) was calculated by multiplying the time spent for the PA domain per day on the relevant cost of metabolic equivalent (MET) under this domain. The total energy expenditure (TEE) was found by summation of the PAcategory-specific EE and expressed in MET (further details may be found at www.ipaq.ki.se). We applied a computer software of our own design to process and analyze the PA data.

The obtained data arrays were statistically processed using the Statistica 10 (StatSoft, USA) software toolkit. We computed the mean arith- metic value $\langle\mathrm{X}>$, median $\langle\mathrm{Me}>$, standard deviation $<\mathrm{SD}>$, and confidence interval $< \pm 0.95 \mathrm{CI}>$. The data arrays were matched using the Student's t-test, and medians were matched using the Wilcoxon matched pairs test with significance rate of $\mathrm{p}<0.05$. Correlations of the TEE with the age and gender were profiled by a single-factor dispersion analysis (analysis of variations, ANOVA) for every physical activity domain (work, transportation, domestic and gardening (yard) activities, and leisure-related activities including walking) with classification into the sedentary, low, moderate and vigorous PA.

\section{Results}

In late 2014 to early 2016, we questioned in total 1640 randomly sampled residents of Surgut city, with 65 women and 23 men being excluded from the data arrays for different reasons. The final sample totaled 1552 respondents including 717 men aged $32.8 \pm 12.7$ years $(36.0 \%)$ and 835 women aged $35.9 \pm 12.4$ years $(64.0 \%)$ : see Table 1. On the whole the table shows the subject men having significantly bigger weight and taller than the women and reporting the higher PA-related weekly energy expenditures.

Professional groups - including the education sector, office personnel, technical personnel (laborers) of different industries and companies, and students - were represented in the Surgut population sample by virtually equal shares varying from $19.14 \%$ (office personnel) to $24.23 \%$ (students): see Table 2.

The only exception was found for the health sector personnel (dominated by physicians and hospital nurses) and pensioners that made up $6.96 \%$ and $6.76 \%$ of the sample, respectively. However, the last two categories are minor in the Surgut population and, hence, the sample may be considered representative of the whole healthsector and retired population of the city. The study found that the specific work-related energy expenditures (EE) reported by men were signifi-

Anthropological data of the sampled Surgut residents, $X \pm S D$

Table 1

\begin{tabular}{|l|c|c|c|}
\hline \multicolumn{1}{|c|}{ Variables } & Men $(\mathrm{n}=717)$ & Women $(\mathrm{n}=835)$ & Overall $(\mathrm{n}=1552)$ \\
\hline Age, years & $34,8 \pm 12,4$ & $34,1 \pm 12,3$ & $34,45 \pm 12,3$ \\
\hline Body height, $\mathrm{cm}$ & $169,4 \pm 8,4^{*}$ & $164,5 \pm 6,3$ & $169,4 \pm 8,4$ \\
\hline Body mass, $\mathrm{kg}$ & $71,7 \pm 14,3^{*}$ & $65,2 \pm 11,94$ & $71,7 \pm 14,27$ \\
\hline Body mass index, $\mathrm{kg} / \mathrm{m}^{2}$ & $25,6 \pm 3,8^{*}$ & $24,1 \pm 4,3$ & $24,9 \pm 4,2$ \\
\hline Energy expenditure, $\mathrm{kcal} / \mathrm{week}$ & $2407 \pm 2094^{*}$ & $2087 \pm 1740$ & $2235 \pm 1918$ \\
\hline
\end{tabular}

Note: *gender-specific difference at $\mathrm{p}<0.05$. 


\section{Спортивная тренировка}

cantly higher ( $\mathrm{p}<0.05$; t-test) than the women's EE, whilst the latter reported spending more energy on the housework ( $p<0.05$; t-test) and transportation $(\mathrm{p}<0.0001 ; \mathrm{t}$-test $)$.

The study data showed no statistically significant gender-specific differences in the leisuretime PA data reported by the Surgut sample, see Figure 1.

Women reported higher specific energy expenditures on moderate PA than men, albeit the latter showed statistically higher vigorous PA rates. The study found no significant differences in the reported total PA and walking-related PA: see Figure 2.

Given on Figure 3 hereunder are the ranged sedentary behaviors by activity categories of the people subject to the IPAQ. The study data are indicative of the low-active subjects mostly grouping in Range 1 and Range 3 with $56.2 \%$ reporting the sitting times of up to 3 hours per day; and $47.9 \%$ of the low-active subjects reporting the sitting times of 6-9 hours per day. The vigorously-active subjects are found mostly grouped in Range 2 with their reported sitting times of 3-6 hours per day.

It may be pertinent to note the extremely high shares of moderately-active individuals falling in the sitting time ranges 4 and 5 (42.8\% and $41.9 \%$, respectively) making $9-15$ hours per day. It means that the sample of permanent Surgut residents was found to include a significant proportion of the people combining moderate physical activity with long sedentary behavior on a weekly basis.

The single-factor dispersion analysis (analysis of variations, ANOVA) showed the workrelated PA reported higher by men: $\mathrm{F}(1,1550)=$ $=26.676, \mathrm{p}=0.0000$; and the transportationrelated PA by women: $\mathrm{F}(1,1550)=21.801, \mathrm{p}=$ $=0.0000$. The leisure-time PA was found gender-

Sample breakdown by professional categories

Table 2

\begin{tabular}{|l|c|c|c|c|c|c|}
\hline \multirow{2}{*}{ Categories } & \multicolumn{2}{c|}{ Women } & \multicolumn{2}{c|}{ Men } & \multicolumn{2}{c|}{ Overall } \\
\cline { 2 - 7 } & $\mathrm{n}$ & $\%$ & $\mathrm{n}$ & $\%$ & $\mathrm{n}$ & $\%$ \\
\hline Education sector & 187 & 12,05 & 168 & 10,82 & 355 & 22,87 \\
\hline Office personnel & 163 & 10,5 & 134 & 8,63 & 297 & 19,14 \\
\hline Students & 216 & 13,92 & 160 & 10,31 & 376 & 24,23 \\
\hline Laborers & 142 & 9,15 & 169 & 10,89 & 311 & 20,04 \\
\hline Health sector personnel & 65 & 4,19 & 43 & 2,77 & 108 & 6,96 \\
\hline Pensioners & 62 & 3,99 & 43 & 2,77 & 105 & 6,76 \\
\hline Total & 835 & 53,8 & 717 & 46,2 & 1552 & 100 \\
\hline
\end{tabular}

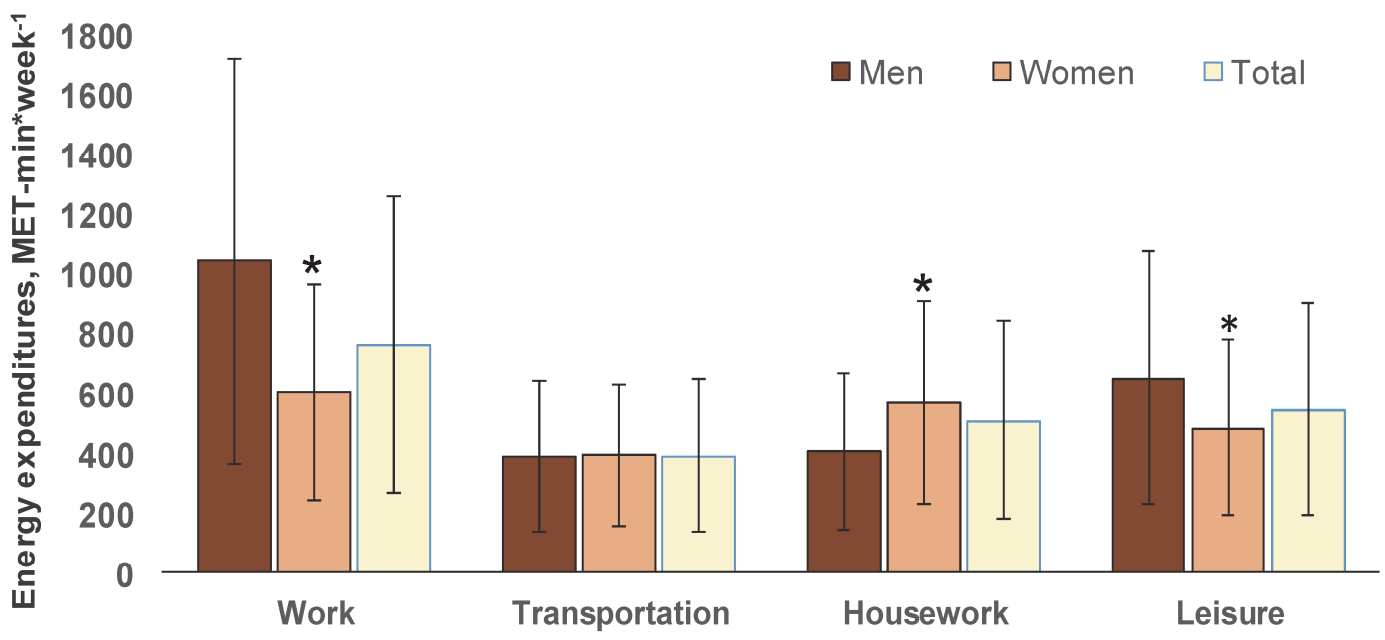

Physical Activity Domains

Fig. 1. Classified weekly energy expenditures (EE) on physical activity reported by the sampled Surgut men $(n=717)$ and women $(n=835)$ subject to the IPAQ, in MET-min/ week, $(X \pm S D)$ 


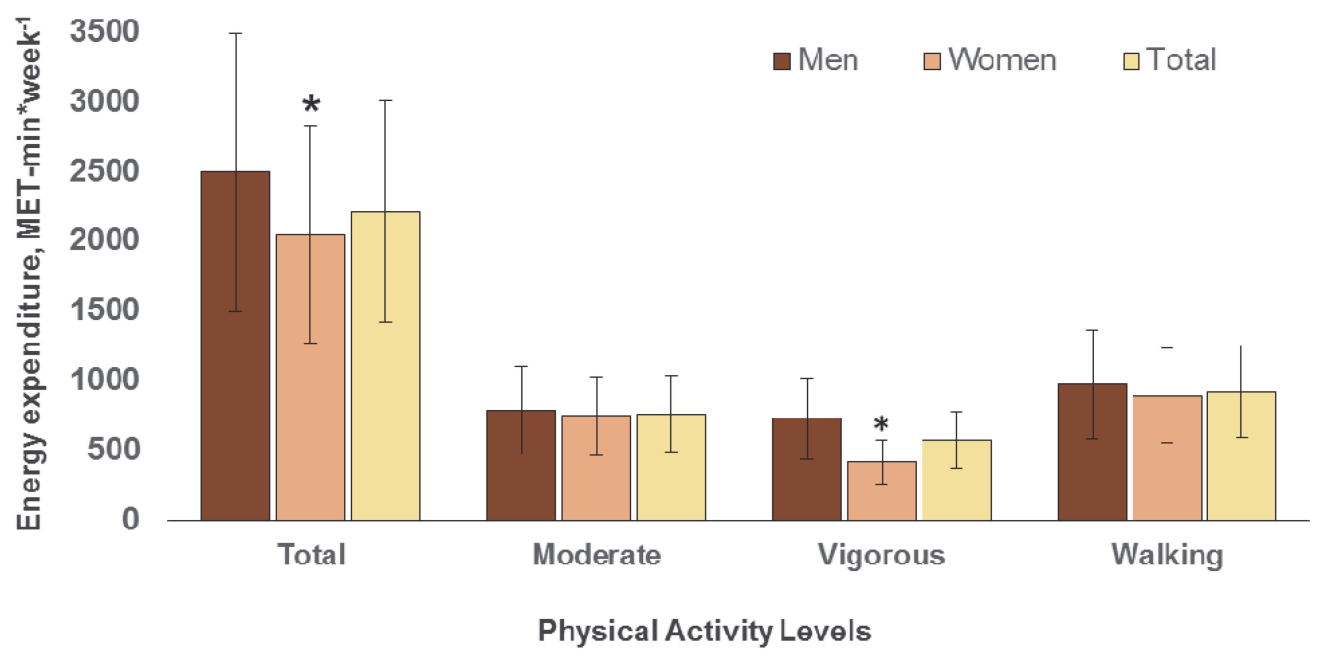

Fig. 2. Classified weekly energy expenditures (EE) on physical activity reported by the sampled Surgut men $(n=717)$ and women $(n=835)$ subject to the IPAQ, in MET-min/ week, $(X \pm S D)^{*}$ significant difference with $p<0.05$

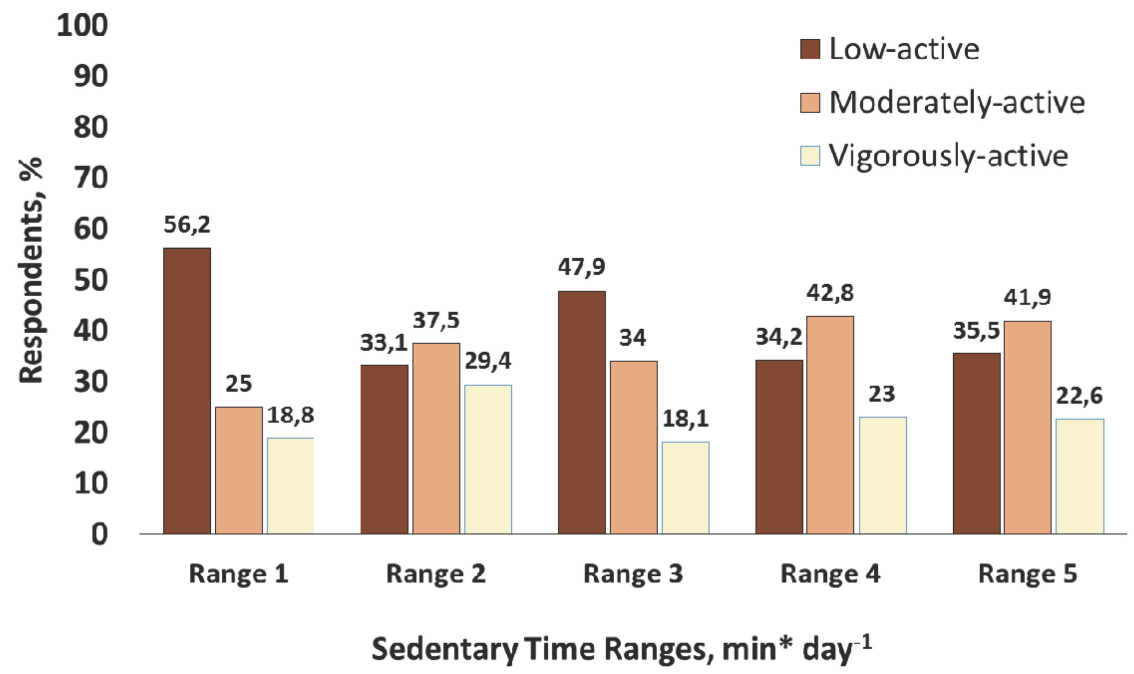

Fig. 3. Physical activity levels versus the ranged sitting times $(\mathrm{min} / \mathrm{day}, \mathrm{n}=1552)$

unspecific with $\mathrm{F}(1,1550)=0.00191, \mathrm{p}=0.9652$. The women reported higher energy expenditures for housework making up $\mathrm{F}(1,1550)=39.338$, $\mathrm{p}=0.0000$. The sedentary time was reported to average $2835.3 \pm 874.2 \mathrm{~min} /$ week $(6.75$ hours per day) being gender-unspecific with $\mathrm{F}(1,1550)=$ $=1.3332, \mathrm{p}=0.2484$.

\section{Discussion}

Positive effects of a moderate-intensity physical activity on human health are well known and commonly recognized today [9]. However, the problem of unorganized population being engaged in everyday physical activity reasonably necessary for health protection still remains largely unsolved. It has lately been aggravated by one more problem of the growing and largely inevitable sedentary behavior that - even when combined with periodical physical activity re- gardless of its intensity - may be highly detrimental for health [5]. A recent meta-analytical study report demonstrated that every extra inactive hour above 7 inactive (sitting) hours per day increases the death risk (irrespective of the causes) by $2 \%$ for the otherwise active adults and by $5 \%$ for the totally inactive ones [6]. It is commonly believed today that the moderate PA taking 60-75 min per day decreases albeit never excludes the increased risk of death due to habitual long sitting, particularly for the people watching TV for more than 5 hours per day [8]. Furthermore, there are study data to confirm that the long daily sitting times habitual for the adults diagnosed with high risks of type 2 diabetes are more detrimental for their cardio-metabolic health conditions and more influential on the latter than whatever physical activity they may otherwise 


\section{Спортивная тренировка}

resort to [10]. Therefore, modern health protection initiatives should be designed so as to reasonably combine the actions to increase the physical activity with the strategies to minimize the inactive/ sedentary behavior as these actions are equally important and interrelated [20].

The study presents the survey data for the Surgut population mostly engaged in the local services and non-industrial production sector and, hence, the sample is relatively homogenous. We are going to report our study data on the petroleum, construction and energy sector personnel's PA and SB in a special upcoming report.

Our measurements under the present study resulted in the total PA of the Surgut residents surveyed - as verified by the total MET-minutes per day for the 5 standard PA domains as per the IPAQ (i.e. the work-time, transportation-time, housework and leisure-time PA) - estimated at 1874 (1798, 1949 CI) MET-minutes per week. This figure is notably lower than those reported by the Norwegian [11] and Croatian [5] respondents: $4240(2155,8916) \mathrm{MET}-\mathrm{min} /$ week and 3492 (3174, 3810) MET-min/ week, respectively; albeit quite comparable with the one reported by the Swedish sample: $1536(861,2856)$ MET$\mathrm{min} /$ week [7]. The Canadian adults from Ontario region reported their weekly physical activity at 4672 (SD 3551) MET-min/week including vigorous- and moderate-intensity PA of 1389 (SD 1878) and 1378 (SD 1591) MET-min / week, respectively. The Surgut respondents reported the vigorous, moderate and leisure-time $\mathrm{PA}$ at 240 (SD 578), 663 (SD 824) и $397(361,433)$ MET-min/ week, respectively, that is by far lower than even the Canadian ones [10].

The increasingly common sedentary habits have been subject for many experimental and theoretical studies for the last few years. According to a large-scale physical activity survey conducted in 32 European nations, the average ac- tive-day sitting time was estimated at 309 minutes (5.25 hours) per day (SD 185), with the countryspecific sitting times varying from $236 \mathrm{~min} /$ day in Portugal to as much as $335-407 \mathrm{~min} /$ day in Germany, Benelux Union and Scandinavian countries [3]. The Canadians who live in much the same climatic conditions, report the sitting times averaging 324 (SD 122) min / day versus 405 (SD 125) $\mathrm{min} /$ day reported by the Surgut adults. Curiously enough, the Finnish adults, as reported by the relevant accelerometer study, spend sitting about $60 \%$ of the wakeful-state time in combination with moderate PA in between the sleep and work times [13].

Therefore, the above data provide more evidence in support of reasonable and regular physical activity, particularly in view of the fact that the share of population engaged in predominantly sitting works and habits is rapidly increasing. Presently the sedentary behaviors in many European countries and Canada are reported to average around 5 hours per day, and many analysts tend to recommend it as a guiding health standard. Our study has found that the average sitting time of the Surgut sample comes to 6.75 hours per day that is notably higher than the European average. Special physical activity encouragement and optimization programs are critically needed today to scale down the inactive and increase the reasonably active shares of population, advance the leisure-time PA and minimize the sedentary behavior.

This work was carried out as part of a state assignment with financial support from the Department of Education and Youth Policy of the KhantyMansi Autonomous Region - Ugra "Development and implementation of new technological solutions to optimize physical activity and health, establishing patterns of the body's response to physical activity of different modality in the Khanty-Mansi Autonomous Region-Ugra".

\section{References}

1. Ainsworth B.E., Haskell W.L., Herrmann S.D. et al. Compendium of Physical Activities: a Second Update of Codes and MET Values. Med Sci Sports Exerc, 2011, vol. 43, pp. 1575-1581. DOI: 10.1249/MSS.0b013e31821ece12

2. Balsevich V.K. Ontokineziologiya cheloveka [Human Ontokineziology]. Moscow, Theory and Practice of Physical Culture Publ., 2000.

3. Bennie J.A., Chau J.Y., van der Ploeg H.P., Stamatakis E., Do A., Bauman A. The Prevalence and Correlates of Sitting in European Adults - a Comparison of 32 Eurobarometer-Participating Countries. Int J BehavNutr Phys Act, 2013, vol. 11 (10), p. 107. DOI: 10.1186/1479-5868-10-107 
4. Bennie J.A., Pedisic Z., van Uffelen J.G., Gale J., Banting L.K., Vergeer I., Stamatakis E., Bauman A.E., Biddle S.J. A Systematic Review of Correlates of Sedentary Behaviour in Adults Aged 18-65 Years: A Socio-Ecological Approach. BMC Public Health, 2016, vol. 25 (16), p. 73 . DOI: 10.1186/s12889-016-2736-3

5. Bouchard C., Blair S.N., Katzmarzyk P.T. Less Sitting, More Physical Activity, or Higher Fitness? Mayo Clin Proc, 2015, vol. 90 (11), pp. 1533-1540. DOI: 10.1016/j.mayocp.2015.08.005

6. Chau J.Y., Grunseit A.C., Chey T., Stamatakis E., Brown W.J., Matthews C.E., Bauman A.E., van der Ploeg HP. Daily Sitting Time and All-Cause Mortality: a Meta-Analysis. PLoS One, 2013, vol. 13, no. 8 (11), e80000. DOI: 10.1371/journal.pone.0080000. eCollection 2013

7. Ekelund U., Sepp H., Brage S., Becker W., Jakes R., Hennings M., Wareham N.J. CriterionRelated Validity of the Last 7-Day, Short Form of the International Physical Activity Questionnaire in Swedish Adults. Public Health Nutr, 2006, vol. 9 (2), pp. 258-265. DOI: 10.1079/PHN2005840

8. Ekelund U., Steene-Johannessen J., Brown W.J., Fagerland M.W., Owen N., Powell K.E., Bauman A., Lee I.M. Lancet Physical Activity Series 2 Executive Committe; Lancet Sedentary Behaviour Working Group. Does Physical Activity Attenuate, or Even Eliminate, the Detrimental Association of Sitting Time with Mortality? A Harmonised Meta-Analysis of Data from More than 1 Million Men and Women. Lancet, 2016, vol. 24, no. 388 (10051), pp. 1302-1310. DOI: 10.1016/S0140-6736(16)30370-1. Epub 2016 Jul 28.

9. Franklin B. Health Implications of Low Cardiorespiratory Fitness, too Little Exercise, and Too Much Sitting Time: Changing Paradigms and Perceptions. Am J Health Promot, 2011, vol. 24 (4). DOI: 10.4278/ajhp.25.4.exi

10. Gauthier A.P, Lariviere M., Young N. Psychometric Properties of the IPAQ: A Validation Study in a Sample of Northern Franco-Ontarians. J Phys Act Health, 2009, vol. 6 (suppl. 1), pp. 54-60. DOI: 10.1123/jpah.6.s1.s54

11. Graff-Iversen S., Anderssen S.A., Holme I.M., Jenum A.K., Raastad T. An Adapted Version of the Long International Physical Activity Questionnaire (IPAQ-L): Construct Validity in a Low-Income, Multiethnic Population Study from Oslo, Norway. Int J BehavNutr Phys Act, 2007, vol. 4 (13). Published online 2007 Apr 20. DOI: 10.1186/1479-5868-4-13

12. Henson J.I., Yates T., Biddle S.J., Edwardson C.L., Khunti K., Wilmot E.G., Gray L.J., Gorely T., Nimmo M.A., Davies M.J. Associations of Objectively Measured Sedentary Behaviour and Physical Activity with Markers of Cardiometabolic Health. Diabetologia, 2013, vol. 56 (5), pp. 1012-1020. DOI: 10.1007/s00125-013-2845-9. Epub 2013 Mar 1

13. Husu Pauliina, Suni J., Vähä-Ypyä H., Sievänen H., Tokola K., Valkeinen H., Mäki-Opas T., Vasankari T. Objectively Measured Sedentary Behavior and Physical Activity in a Sample of Finnish Adults: a Cross-Sectional Study. BMC Public Health, 2016, vol. 16 (1), p. 920 . Published online 2016 Sep 1. DOI: 10.1186/s12889-016-3591-y

14. IPAQ Research Committee. Guidelines for Data Processing and Analysis of the International Physical Activity Questionnaire (IPAQ) - Short and Long Forms, 2005. http://www.ipaq.ki.se/ scoring.pdf. Accessed August 11, 2016.

15. Jurakić D., Pedisić Z., Andrijasević M. Physical Activity of Croatian Population: CrossSectional Study Using International Physical Activity Questionnaire. Croat Med J, 2009, vol. 50 (2), pp. 165-173. DOI: $10.3325 / \mathrm{cmj} .2009 .50 .165$

16. Loginov S.I. Fizicheskaya aktivnost: metody otsenki I korrektsii [Physical Activity. Methods of Evaluation and Correction]. Surgut, SSU Publ., 2005.

17. Loginov S.I., Nikolayev A.Yu., VetoshnikovA.Yu., Sagadeeva S.G. Evaluation of Physical Activity of Surgut Residents According to International Questionnaire IPAQ. Theory and Practice of Physical Culture and Sport, 2015, vol. 1, pp. 83-85.

18. O'Donoghue G., Perchoux C., Mensah K., Lakerveld J., van der Ploeg H., Bernaards C., Chastin S.F., Simon C., O'Gorman D., Nazare J.A. DEDIPAC Consortium. A Systematic Review of Correlates of Sedentary Behaviour in Adults Aged 18-65 Years: a Socio-Ecological Approach. BMC Public Health, 2016, vol. 17 (16), p. 163. DOI: 10.1186/s12889-016-2841-3 


\title{
Спортивная тренировка
}

19. Olson E.A., McAuley E. Impact of a Brief Intervention on Self-Regulation, Self-Efficacy and Physical Activity in Older Adults with Type 2 Diabetes. J Behav Med, 2015, vol. 38 (6), pp. 886-898. DOI: 10.1007/s10865-015-9660-3. Epub 2015 Jul 11.

20. Puig-Ribera A., Martínez-Lemos I., Giné-Garriga M., González-Suárez Á.M., Bort-Roig J., Fortuño J., Muñoz-Ortiz L., McKenna J., Gilson N.D. Self-Reported Sitting Time and Physical Activity: Interactive Associations with Mental Well-Being and Productivity in Office Employees. BMC Public Health, 2015, vol. 15, p. 72. DOI: 10.1186/s12889-015-1447-5

21. Rao D.P., Orpana H., Krewski D. Physical Activity and Non-Movement Behaviours: Their Independent and Combined Associations with Metabolic Syndrome. Int J BehavNutr Phys Act, 2016, vol. 19 (13), p. 26. DOI: 10.1186/s12966-016-0350-5

22. Sedentary Behaviour Research Network. Letter to the Editor: Standardized Use of the Terms "Sedentary" and "Sedentary Behaviours". Applied Physiology, Nutrition and Metabolism. 2012, vol. 37, pp. 540-542. DOI: 10.1139/h2012-024

23. Sorensen M.V., Leonard W.R., Tarskaya L.A., Ivanov K.I., Snodgrass J.J., Alekseev V.P., Krivoshapkin V.G., Rifai N. High-Sensitivity C-Reactive Protein, Adiposity, and Blood Pressure in the Yakut of Siberia. Am J Hum Biol, 2006, vol. 18 (6), pp. 766-775. DOI: 10.1002/ajhb.20547

24. Zwolinsky S., McKenna J., Pringle A., Widdop P., Griffiths C., Mellis M., Rutherford Z., Collins P. Physical Activity and Sedentary Behavior Clustering: Segmentation to Optimize Active Lifestyles. J Phys Activ Health, 2016, vol. 13, pp. 921-928. DOI: 10.1123/jpah.2015-0307

Received 30 August 2019

Удк 796.012.4

DOI: $10.14529 / \mathrm{hsm} 190409$

\section{ФИЗИЧЕСКАЯ АКТИВНОСТЬ И МАЛОПОДВИЖНОЕ ПОВЕДЕНИЕ ВЗРОСЛЫХ ЖИТЕЛЕЙ ГОРОДА СУРГУТА}

\author{
С.И. Логинов \\ Сургутский государственный университет, г. Сургут, Россия
}

Цель. Физическая активность (ФА) успешно изучается с помощью международного опросника IPAQ. Впервые за последние 20 лет в России в настоящей статье идентифицированы уровень и структура физической активности и малоподвижного поведения с помощью русскоязычной версии опросника IPAQ. В исследовании участвовали 1552 жителя г. Сургута (717 мужчин, 835 женщин, возраст 34,4 $\pm 12,6$ года) - представителей преимущественно умственного труда. Результаты. О низкой ФА сообщили 40,7 \% выборки, умеренной - 36,3 \%, высокой - 23,0 \%. Продолжительность физической активности на работе составила в среднем 25 мин/день (23; 26 ДИ), при передвижениях - 17 мин (16; 19 ДИ), во время выполнения работы по дому - 18 мин (17, 19 ДИ), на досуге - 12 мин/день (11, 13 ДИ). Дисперсионный анализ показал, что ФА на работе существенно выше у мужчин $(\mathrm{F}(1,1550)=$ $=26,676, p=0,0000)$, а при передвижениях - у женщин $(\mathrm{F}(1,1550)=21,801, \mathrm{p}=0,0000)$. Досуговая ФА не имеет гендерной зависимости - F $(1,1550)=0,00191, \mathrm{p}=0,9652)$. Женщины тратят больше энергии на работу по дому $-\mathrm{F}(1,1550)=39,338, \mathrm{p}=0,0000$. Время сидения составляет в среднем $405 \pm 125$ мин/день $(6,75$ часа в день - нижняя граница зоны риска) и не зависит от пола $-\mathrm{F}(1,1550)=1,3332, \mathrm{p}=0,2484$. Выявлены группы людей, имеющих в течение недели различные комбинации сидячей деятельности и физической активности умеренной и высокой интенсивности. Заключение. Необходимы специальные программы оптимизации уровня ФА, направленные на снижение доли низкоактивных и повышение доли умеренно активных жителей, повышение времени досуговой ФА и снижение продолжительности малоподвижного поведения.

Ключевые слова: повседневная физическая активность, уровень и структура физической активности, урбанизированный Сибирский Север, сидячее поведение, IPAQ. 
Логинов Сергей Иванович, доктор биологических наук, профессор, главный научный сотрудник научно-образовательного центра Института гуманитарного образования и спорта, Сургутский государственный университет. 628412, г. Сургут, пр. Ленина, 1. E-mail: logsi@list.ru, ORCID: 0000-0002-6640-3385.

Поступила в редакцию 30 августа 2019 z.

\section{ОБРАЗЕЦ ЦИТИРОВАНИЯ}

Loginov, S.I. Daily Physical Activity and Sedentary (Inactive) Behaviour of Adults from Surgut / S.I. Loginov // Человек. Спорт. Медицина. - 2019. - Т. 19, № 4. C. $70-77$. DOI: $10.14529 / \mathrm{hsm} 190409$

\section{FOR CITATION}

Loginov S.I. Daily Physical Activity and Sedentary (Inactive) Behaviour of Adults from Surgut. Human. Sport. Medicine, 2019, vol. 19, no. 4, pp. 70-77. DOI: $10.14529 / \mathrm{hsm} 190409$ 